\title{
QUISCUIUS QUISCUIA
}

Quisculus Quiscula, Yorkton's one-legged tourist, is dead. Quis was a one-legged bronze grackle who for the past four consecutive years has spent his summers hopping around the city hall law.

Early this fall, caretaker Alex Yacina found Quis stretched out at the bottom of a tree. He took quis to the city hall basement for treatment, but the old fellow failed to recover.

How Quis lost his leg is a mystery but the good leg carried a small metal band. The band was sent to the American Fish and Wild Iife Service, where Quis' obituary will be recorded for science.

Word has been received back that this bird was a female, banded September 4, 1946, by Stuart Houston, of Yorkton.

\section{THE HEATHER-IINED NEST . By Doug Gilroy}

I have read of people finding bees asleep in flowers. Here is one about a mouse under similar, yet different conditions.

Around our yard at the farm, the fence posts are of cedar. One of the posts split open, revealing a hollow chamber near the base. A little House Wren wasn't long in finding it and immediately turned it into a summer home -- or should I say, a maternity home, for five young wrens were raised there. As summer waned the wren family packed their grips and departed for the south lands.

A week or so after the departure I was passing by, and for some unknown reason stopped at the post and peered into the opening. What did I see looking at me, with big sleepy eyes, but a white-footed mouse, all curled up snug and warm in the feather-lined nest. This, no doubt, is a common occurrence al. over the country -- but I thought it kind of cute.

\section{YELIOW HORN}

This story comes to us for Cowican, British Columbia:

Yellow Horn, a four-year old deer, is getting as domesticated as a cat. For one thing, he's sleeping on a bed most of the time.

The buck had moved in with Mr. and Mrs. G. C. Boyd in this Vancouver Island village. He started by sleeping on the veranda. He didn't take too well to the hard floor and later sneaked into the house at every chance and snuggled down on the bed.

After that, it wasn't long before he was nipping into the kitchen to nibble at a loaf of bread, or a bowl of fruit in the dining room.

Loggers who first adopted him painted the horns yellow for easy identification by hunters. 


\section{FURRED AND FEATHERED FRIENDS AT BIG RIVER By Anne OIson}

(We are pleased to welcome as a new member, Mrs. S. O. Olson, of Big River, Saskatchewan. Mrs. Olson is an enthusiastic naturalist and a devoted friend to the wildlife of the North. Her reports will be invaluable as a nature connecting link between the prairie and our great wooded area. We hope. to hear from her often. ED.)

Winter seems to be here again in the north. The winter birds come every day for food, and for feeding from dawn till dusk. Some years: ago I heard rather a good suggestion on the radio regarding their feeding. "This idea was to crochet bags from string with a coarse mesh; run a drawmstring through the top and fill with suet. The string bags provide the birds with an ample supply of food for days and also prevent the larger birds, such as the Canada Jays, from carrying the suet elsewhere. I fastened an old clothes drier above one of the kitchen windows and have these bags hung from each arm. From an artistic viewpoint, this arrangement leaves much to be desired perhaps; but the number of feathered visitors is ample compensation.

There are innumerable Chickadees, White Breasted Nuthatches, Downy and Hairy Woodpeckers that come to the window every day. The Chickadees become very tame, eating from the hand quite readily and perch on one's head and shoulders. Last winter two made a practice of flying into the kitchen any time the door was left open a short time. The Canada Jays will also eat from the hand but. it takes time and patience to teach them to do so.

Trays, containing crumbs are always on the window sill. Hazel nuts, when there are any; ar'e there for the red squirrels. Last winter about twe Ive came for food every day. They were very tame and would eat from my himd and climb on my shoulder. Every evening a pair of flying squirrels appeared at dusk. As there wére only two we named them Moonbeam and Batwing. The former would accept food but Batwing refused to come near.

The birds soon come to rely on a plentiful supply of food and become dependent to the extent that if food is not forthcoming they might starve. So it is well to remember that the practice, if started, should be continued without fail.

On september 2Ist a flock of approximately forty geese were seen. This is the earliest migration observed during our six years of residence in the north. The next flock passed over on October 18th, closely followed by several for three days.

There were a great many hummingbirds around the garden during the sumer. They appeared to be especially attracted by red flowers and constantIy visit the Scarlet Runners and red sweet peas.

Are Pileated Woodpeckers common in Saskatchewan? There was only one noted here until last spring when a pair were observed. They are frequently quite close to the house.

(Mrs. I. M. Priestly reported in the second issue of the BLUE JAY that Mr. F. Baines had. seen a Pileated Woodpecker, at Tisdale, early in the winter of 1943. Ordinarily this bird is at home in the northern forests and is only rarely seen in the southern part of the province. Mir. C. Stuart Houston in his "Birds of the Yorkton District" has this to say: "A bird of the northern woods, occurring at Crystal Lake. J. Gunin noted only two individuals at Good Spirit: Lake in sixty years; "one of these was seen in the 
autumn of about 1936, the other in the spring of 1942. Also one noted by M. Heintz, in the springs of 1940 and 1941, on a telephone pole in front of Yorkton Coliegiate (unverified)."

\section{SUNDER BIRDS AT GRENHEII By Mrs. F. Bilsbury}

our summer, in fact, our whole season, has been late from start to almost finish, yet many things havo remained quite unchanged in our animals and bird life and again many things were changed.

The Prairie Horned Larks came before the end of January and were very prevalent. The bluebirds came late, long after the snow had gone. One pair, the very first, tried nesting in an outhouse. They had their nest up and four eggs laid, when a terrible hail-storm accompanied by a cyclonic. wind overturned the building. They left, but returned with five young. I knew it to be the same pair because the female went to look over her first nesting place.

I notice.this season that nearly all songbirds stayed but a few weeks and were seen no more. Robins, orioles, thrashers, a Mocking Bird, thrushes, tree-creepers, warblers and one catbird were seen. Ducks were plentiful and many varieties noted.

Gary, my son, called me to come and see a flock of some twenty or thirty pelicans going south on July 10. These are the first I have seen. We noticed two large flocks of Snow Geese and three or four of Canada Geese and one flock of small dark geese which could have been Lesser Canada going north rather late in the season. Bitterns have been fairly abundant. This morning (September 7) Gary noted a large "blue" or Sandhill Crane in slow flight. One leg dangled so we assumed it had been shot at. Crows seem in goodly numbers and at one time I counted fifty hunting cutworms on a piece of land we knew to be infested. Very few hawks were noted and only one owl.

\section{NOT EVEN. A STUB}

By Mrs. J.M.Powell, Lancer.

A small "grey bird" with only one leg has returned to us three summers in succession. On the third summer it disappeared. Perhaps a cat got it.

It was very interesting to watch it balance on one foot, hop along and even scratch for food. When it was windy it would sit down. We could get quite close to it and there was not even a stub near the body.

Several pairs of Baltimore Orioles make their home on our farm since the tree-belt became high and thickly-leaved.

\section{$--\cdots-$}

\section{TYRANNUS KINGBIRD}

By A. Ward

The Tyrannus Kingoird, one of the most wary of our birds and hard to trap, never returns here in the spring until about. the twelfth of May, when the leaves are well out and insect food available. They are not averse to taking a diet of bees and will sit on the fence to catch them coming to and leaving the hive. With all favorable conditions existing about September l2th, they leave for the south with no apparent pressing reason.

One of these immature birds was banded at Burnham, August 8th, 1949, and was found dead on the street in Swift Current with a broken wing, July 21 ,
1950. 
The Grove has been very lonesome (September 1). No birds have been here for the past few days which have been fine and warm. All the migratory birds observed here to date are two Oven Birds, two Nuthatches, one Redstart and a few immature Clay-coloured Sparrows.

I was interested in reang the following letter from the Canadian Wildlife Department, Ottawa:

"It was of interest to note that you reported placing band $N, \cdots 48$ 243432 on an adult male Varied Thrush at Burnhám, Sask., on September 27, 1949. Since Burnham is rather far removed from the normal range of this species, we should appreciate any further particulars you may be able to supply that would help. substantiate this interesting record."

It would seem that if attraction is widespread there is Iess means of concentration than is usual around the Farm Grove. This has been very noticeable throughout the year. Water and great quantities of natural food everywhere has directed migration into much broader channels of widespread proportions.

In accordance with these facts banding at this station has been very disappointing. Only 249 birds, of 31 species, were banded. On the other hand outlying districts have greatly benefited by the scattered movement.

It has been noted that over a number of years, the Slate-coloured Junco and the Tree Sparrows are the first to return in the spring, commencing late in March; also that these two species are the last to go south, departing during the latter part of october.

Birds banded at Burnham during 1950, in A.0.U. order: Tyrannus Kingbird (1), Says Phoebe (3), Barn Swallow (5), Red-breasted Nuthatch (1), House Wren (3), Catbird (7), Brown Thrasher (7), Robin (11), Olive-backed Thrush (12), Orange Crown Warbler (1), Yellow Warbler (12), Nyrtle Warbler (13), Oven Bird (1), Wilson Warbler (1), American Redstart (1), Redwing Blackbird (12), Baltimore Oriole (1), Bronze Grackle (1), Pine Siskin (2), Red Crossbill (I), Eastern Towhee (I), Slate-coloured Junco (60), Pinksided Junco (1I), Tree Sparrow (1I), Chipping Sparrow (4), Claymcoloured Sparrow (10), Harris Sparrow (2), White Crown Sparrow (37), White-throated Sparrow (4), Lincoln Sparrow (6), Song Sparrow (6), Chestnut-coloured Longspur (I).

\section{THE GRASS SNAKE AND THE WHITE CROWN}

With much moisture and cool weather it was not surprising to see so many snakes and frogs around the garden. On going over to take a bird out of the trap I found a 26-inch snake in with it. Both were so intent on getting out of there that they paid little attention to each other. The bird, a Wite Crown Sparrow, had been caught and banded before.

\section{ANARICAN SPARROW HAWK}

By C. C. Shaw

The opening of the hunting season in this district, October 2 , brought the death of an American Sparrow Hawk. The hunter said he had swung quickly and fired, mistaking the bird for a teal.

Q. Stuart Houston, in his "Birds of the Yorkton District," records that the Sparrow Hawk was once a common summer resident, now markedly decreased in numbers. The latest fall date previously noted was Sept. 7, 1945. 
Winter came earlier this season than for many years. Usually when the lakes first freeze over, they break up again with warmer weather, but this time when the freeze-up occurred.iNovember 6 , the ice stayed on and the weather has been cold and winter-like ever since.

Despite the fact that it has been a cooler summer than usual the fall migration started about the same time. Sandpipers and Yellowlegs were first noted going over, August 3, followed on August 10 by flocks of Tree Swallows and Canada Geese.arriving here from further north. They go to the larger lakes as soon as the young. are able to fly and stay all summer, coming back in the fall to. feed in the grain fields. Also about this time large flocks of White Pelicans were flying past here every morning and night. During most of the month of August they kept this up - going north-west in the morning and back at night. We were wondering if they were in training for the long flight south. They fly between the lakes, probably going to the large lakes like Fishing Lake to the northwest and Good Spirit Lake to the southeast where there are small fish which they feed on. They were seen last on September 5 .

About the last week of August and most of September we had the largest concentration of crows I have ever seen. They do not nest around here so much now, as much of the bush has been removed to make larger fields. But this fall they must have come in from many districts farther north and east, I was wondering if this was because the crops were badly frozen north and east, while they escaped much of the frost here. Anyway, the crows seemed to think it.was a great place for them to stay - plenty of foed and water. They settled down for about three weeks feeding on ours and the neighbours' crops. They can do a great deal of damage when they start, especially when there are about half a million of.them, as it seemed to me. After I shot a few and left thom or the stooks, the others took the hint and mored further south.

Very cool weather with first light frosts occurred August 16 and 18, which started the migration of warblers and sparrows from the north. The main migration did not come until september. Large numbers of Palm Warblers were noted around september 8. Nountain Bluebirds in large flocks were seen September 1l. Pine Siskins were also around in small numbers. September 26 was the end of an extremely warm dry spell. Large numbers of birds were driven down ahead of cold; snowy, winterlike weather. Many warblers passed through. Also many kinds of sparrows; including Harris, White-throated, Tree and Iincoln. Large flocks of Bluebirds, Brewers Blackbirds, Robins, Meadowlarks, Smith's and Lapland Longspurs were seen. About this time cranes and Iesser Canada Geese were seen going southeast high up. On October 28 there was a light snow followed by cold, freezing weather, so the heary migration was a sure sign of the cold spell to come.

The first snow Buntings arrived. October 20. About this time a Raven was noticed in the district. They had been seen here several years ago but are rather rare in this district. The first Common Redpolis, in small flocks, arrived october 24. A Short-eared Owl was noticed on a fencepost, October 27. They are. not often seen here. Evening Grosbeaks in small numbers were seen october 27. The Pine Grosbeaks arrived November 2. The Whistling Swans came down from the north in migration, November 6. They passed right over, non-stop, a sure sign of freeze-up. The lakes froze over this same night and winter started in earnest.

This has been one of the earliest freeze-ups I remember. One Bohemian Waxwing was noted on November 8 . So most of the winter residents
have arrived. 
All summer the Neadowlarks have again mado their summer home in the grass close around my house. About three pairs nested there, but as far as I could ascertain only two birds grew to maturity.

Late in September, as the birds were moving south, a dozen or more assembled for a brief stay. A few more stragglors appeared from.day to day; some even sang feeble songs during mid-October.

To my pity and surprise I saw the last group on October 21. The day was cold and they were searching desperately for food. Under the fence and in leaf piles in my garden they managed to salvage some dead grasshoppers. There were four of them. is they rested they were seen preening their feathers in the sun. Joined by two others they departed that day. It is my sincered hope that they arrived safely at their distant winter homeland.

$$
\frac{\text { THE HONEY BOTTLE }}{\text { By Madeline B. Runyan, }}
$$

My little Hummingbird returned to drink at" the honey-bottle on my window, during early June, and was there from dawn to early dusk all summer with the exception of sixteen days. During this time I feared she had met with grief but concluded later that she was nesting."

On August 26, a stranger appeared at the, honey. There were a few sharp battles outside the window and the original bird was routed and did not return. The newcomer, although very nervous, monopolized the honey supply until she migrated on September. 5 .

I took a very good close-up picture of the bird sipping honey. As yet I have not had a ruby-throated male at the window.

\section{HUNGAPIAN PARTRTD GES}

These birds seem to have made a come-back. After near extinction at Punnichy, they are fairly plentiful now.

On November 10, as I drove along a prairie road at dusk, I ran: onto a flock of these little partridges, feeding on wheat dropped from loaded trucks. As they rose in flight, I was surprised to see a large Snowy Owl rise from a telephone pole and follow them. (This was in the semans district. The snowy Owl is seldom seen in the parkland where we live.)

Is October 22 not a very late date for Robins? A small flock was seon here on that date, probably in migration, and certainly belated. (Mr. Jordan will answer this. ED)

\section{AVIITOR OF THE EVENING SKIES $\quad$ By S. P. Jordan}

I don't know how common it is to have a Nighthawk sleep beside your bedroom window ledge, but common or not my wife and I were certainly pleased to have such an intimate visit by this sly and skillful aviator of the evening skies. I don't know if he became hungry or whether the sun became too warm, possibly it was a combination of both, but he left his resting place at 1.30 in the afternoon on August 27. 
A person tends to take robins for granted in the spring and summer months, for he sees and hears dozens daily. But in the fall as in the early spring, such thoughts as, "Well, what are. you doing here all by yourself" bespeak of particularized interest. In other words, your "robin appreciation" so to speak, is somewhat similar to a human's appreciation of his fellows. After the sad passing of a friend one might remark, "Yes, I miss him now that he is gone." In other words the robin gains by going.

The reason for writing the above paragraph is that I thought it would help in explaining my feelings when on a cold wintery day, (November 12) I had the pleasure of seeing a derelict "king of the lawn." He was eating thorn berries, attended by a flock of 20 to 25 Bohemian Waxwings.

\section{SASKATCHEWAN PRAIRIE CHICKEN DANC ING GROUNDS}

Paswegin -. Centre of N.W. 17 - 35. - 14, W 2nd

Bladworth $\rightarrow$ N.W. $27-28-1$, Wrd

- S.E. $36-28-1$ W of 3rd

Duval - S.E. 26-25-2I W of 2nd

Wauchope - S.W. $15-8-33$ W of. Ist

Grenfell (Mrs. Bilsbury) A mile south of farm

Grenfell (Mrs. Bilsbury) S.E. Section 13

Regina, 20 miles N.W. -- S.W. 5 - 19-2I

Grenfell - N.W. 25-8- $18 \mathrm{~W}$ of 2 nd

Grenfell. - S.E. 25-8- 18 W of 2nd

Grenfell - N.W. $5-7-18 \mathrm{~W}$ of 2 nd

Iipton - S.W. $30-24-14$

Iipton - S.W. $13-24-14$

Clashmore (Reported by E.W. Arnold, of Valparaiso)

Strasbourg (Reported by Miss Anita"Coneybears)

Saltcoats - N.W. quarter of $T 23-3-W$ 2nd

Saltcoats -- Five miles west of town on either side of the road.

Leask. - (G.C. Coates farm) - North edge of T $46-5$ - W of $3 r d$

The Saskatchewan Department of Natural Resources would like to learn of the locations of any other Dancing Grounds in the province.

\section{CHRISTMLAS BIRD COUNT}

The value of taking a mid-winter bird census as well as keeping a careful record of bird migrations at all seasons was emphasized by Mr. W. Yanchinski at our annual meeting.

This year's bird count will be the 9 th consecutive one for the Society and it is our hope that during the last week of the year a new record will be set as to the number of species observed. In 1948, 36. species were observed and last year the total was 24. The total number of species observed to date is 60. No new ones were recorded last year, but in 1948 the presence of Cedar Waxwings and the Pigeon Hawk added two more to the list.

All records of this count should be mailed to the editor not later than January 15. This is necessary in order to give one of our ornithologists sufficient time to check them and to make a summary of the entire picture. 